Maurice A. Deane School of Law at Hofstra University Scholarly Commons at Hofstra Law

Hofstra Law Faculty Scholarship

2014

\title{
Law-Making and the Law of the Sea: The BP Deepwater Horizon Oil Spill in the Gulf of Mexico
}

James E. Hickey Jr.

Maurice A. Deane School of Law at Hofstra University

Follow this and additional works at: https://scholarlycommons.law.hofstra.edu/faculty_scholarship

\section{Recommended Citation}

James E. Hickey Jr., Law-Making and the Law of the Sea: The BP Deepwater Horizon Oil Spill in the Gulf of Mexico 269 (2014)

Available at: https://scholarlycommons.law.hofstra.edu/faculty_scholarship/1218

This Book Chapter is brought to you for free and open access by Scholarly Commons at Hofstra Law. It has been accepted for inclusion in Hofstra Law Faculty Scholarship by an authorized administrator of Scholarly Commons at Hofstra Law. For more information, please contact lawcls@hofstra.edu. 


\title{
16 Law-making and the law of the sea The BP Deepwater Horizon oil spill in the Gulf of Mexico
}

\author{
James E. Hickey, Jr.
}

'The Technology laws and regulations, and practices for containing, responding to and cleaning up spills lag behind the real risks associated with deepwater drilling into large, high pressure reservoirs of oil and gas located far offshore and thousands of feet below the ocean's surface'.

National Commission on the BP Deepwater Horizon oil spill and offshore drilling. ${ }^{1}$

\section{Introduction}

One obvious reason to 'make' international law is to reduce uncertainty in planning future human enterprise. This is no less true for the international law of the sea than it is for other substantive areas of international law. The 2010 BP Deepwater Horizon explosion and oil spill in the Gulf of Mexico underscores how the emerging new reliance on deepwater and ultradeepwater ocean drilling and production of vast new oils reserves below the deep ocean floor raises legal uncertainties about the effective application of the existing law of the sea to address this sort of activity now and in the future. The question is an important one for several reasons. First, over a half of new discoveries of oil and gas reserves are found in deepwater zones. ${ }^{2}$ Second, increasingly oil and gas development is moving away from landbased sources. Third, the indisputable link between global and gross domestic product (GDP) and the availability of affordable and reliable sources of energy continues to be an economic reality.

Recently, a series of laws have been applied after the Deepwater Horizon accident to assign responsibility and exact penalties. BP has agreed to pay fines and penalties under US domestic law of about USD 4.5 billion, to plead guilty to 14 criminal charges and to settle civil charges under US securities

1 Deep Water: The Gulf Disaster and the Future of Offshore Drilling-Report to the President (US Government Printing Office, 2011).

2 'Oil's Future is in Deepwater Drilling', CNN Money, 11 January 2011, <money.cnn.com/ 2011/01/11/news/economy/oil_drilling_deepwater/index.htm>. 
laws. ${ }^{3}$ It also faces additional penalties under the US Oil Pollution Act of 1990 and the Clean Water Act. And two BP supervisors have been indicted for criminal manslaughter. Going forward, a larger fundamental question looms about jurisdiction to act to prevent spills and accidents involving deepwater and ultra-deepwater oil and gas drilling and production. One area of uncertainty involves the current law of the sea.

This chapter lays out the essential relevant facts of deepwater and ultradeepwater drilling and production in the context of the BP Deepwater Horizon oil spill in the Gulf of Mexico and it raises some of the potential legal uncertainties surrounding the applicable international law of the sea that may need to be addressed now and in the future. Those law of the sea legal uncertainties include the legal status of deepwater oil rigs and production facilities, the jurisdiction of coastal states that are exposed to potentially catastrophic harm from deepwater and ultra-deepwater drilling and production accidents such as the BP spill and the harm to the marine environment, especially to unique and discrete deepwater marine ecosystems.

\section{Deepwater and ultra-deepwater drilling in the context of the BP Deepwater Horizon oil spill ${ }^{4}$}

On the 20 April 2010 the BP Deepwater Horizon oil drilling rig exploded causing a 'blowout' (discharge of oil) in the Gulf of Mexico over 40 nautical miles (74 kilometres) off the coast of the US state of Louisiana. By any measure, this was the largest offshore oil drilling and production accident in US history. It has also produced wide-ranging effects of catastrophic proportions. The rig was owned and operated by Transocean and leased to BP and it flew the flag of the Marshall Islands.

\subsection{The effects of the spill}

The drilling rig floated in 4,992 feet (1,522 metres) of water and the oil reservoir being drilled was located another two and one half miles (about four kilometres) below the seabed. Over the three months following the explosion, an estimated total of 4.9 million barrels of oil (some 206 million gallons or 780 million litres) was discharged into the ocean waters of the Gulf until it was stopped in July of 2010. By way of contrast, the 1989 crash of the oil tanker, Exxon Valdez, in Prince William Sound Alaska discharged nine million gallons (34 million litres) of oil.

The current estimate of the combined spill costs including clean up, natural resource damages, economic losses, domestic law penalties, etc. is about USD 41 billion and counting. Additional fines and penalties could

3 Clifford Kraus and John Schwartz, 'BP Will Plead Guilty and Pay Over \$4Billion', The New York Times, 16 November 2012, A1.

4 Unless indicated otherwise, this section draws heavily from Deep Water, supra note 1. 
drive the costs several tens of billions of dollars higher. ${ }^{5}$ At one point, 47,000 people and 7,000 vessels were involved to respond to the spill. A year and a half later, there were still about 1,000 personnel involved in the Gulf region. In addition to state government claims - the US Gulf Coast states are Alabama, Florida, Louisiana, Mississippi and Texas - and federal government claims, over 100,000 private claims have been made for property and economic losses.

The immediate natural resources effects from the oil discharged included harm to shell and finfish - including to crabs, shrimp, oysters, jellyfish, sea turtles, tuna, sharks, snapper, grouper and marlin. Ocean mammals such as whales and dolphin were also affected. Birds (sea and land) like pelicans, osprey, bald eagles, peregrine falcons, northern gannets and laughing gulls suffered harm from oiled feathers and oil ingestion. The spill also affected floating seaweed beds and phytoplankton. Some 1,100 miles (1,769 kilometres) of coast was affected, including impacts felt by beaches, salt marshes and mangrove swamps.

Unique to an oil spill at depths of deepwater (over 1,000 feet or 300 metres deep) and ultra-deepwater (over 10,000 feet or three kilometres deep) are the effects experienced by the discrete deepwater marine ecosystem. The Macondo well, at which the Deepwater Horizon operated, occurred in the deep ocean bathpelagic zone (3,300-13,000 feet or one to four kilometres deep). It is only relatively recently that deepwater and deep seabed areas have been discovered to have unique (intense pressure, cold temperatures and little or no light), rich and diverse marine habitats that include cold water corrals, fish, light-producing worms and giant squid. The deepwater ecosystem of the Gulf was exposed to massive amounts of discharged oil from the BP spill. Oil on the seabed in very cold deepwater habitats dissipates slowly. The nature and severity of the impacts to the deepwater ecosystem around wellhead site, shortand long-term, are not yet known or quantifiable.

Economic losses were suffered by all aspects of tourism and fishing (commercial and sport) as well as by disruptions to other oil and gas operations in the Gulf, all of which are critical activities to the Gulf coast communities. The indirect long-term economic (and environmental) effects on consumer confidence (tourists, fishers and fish eaters, etc.) and to the Gulf coast marketing 'brand' are unknown but no less real. In a larger economic market context, the fishing resources of the Southern coastal US (including the Gulf) produce more than a third of the total US seafood supply and the Gulf of Mexico, in particular, produces a third of the US domestic oil supply, an increasing amount of which is from deepwater reservoirs.

The BP Deepwater Horizon oil spill also affected human physical and mental health. Immediately, 11 people died and the explosion of the rig injured 17 people. The larger human community suffered from fear, anxiety, stress and 
depression with the direct and indirect consequences that this produces on families, friends and colleagues. Such effects almost certainly will never be reduced to accurate financial calculation much less be the object of monetary compensation.

\subsection{The growing phenomenon of deepwater and ultra-deepwater oil and gas drilling and production}

The ability to drill for oil and gas at deepwater and ultra-deepwater is a technology that has rapidly emerged only since the late 1990s. Prior to the 1990s, offshore oil exploitation was at relatively shallow depths close to shore and used more or less a traditional, decades-old, platform technology fixed structurally in some manner to the seabed.

This new deepwater and ultra-deepwater exploitation technology opens a potentially dominant new frontier of ocean exploitation of oil and gas far offshore at unprecedented water depths. It also presents new challenges and risks not encountered before in several respects.

First, there is a huge potential for significant oil recovery from deepwater zones. It is plausible that deepwater and ultra-deepwater drilling will become ubiquitous in the decades ahead. Some of the deepwater fields found to date have over a billion barrels of oil potential. They are so large that they are often described as 'elephants'. In 1990 in the Gulf of Mexico, most oil and gas recovered came from shallow water reservoirs at less than 250 feet (about 75 metres) below the surface of the ocean and relatively near the coast. However, by 1998, less than a decade later, the weighted average of oil production came, not from shallow water reservoirs, but from deepwater wells.

The new phenomenon of deepwater oil and gas exploitation is not confined to the Gulf. Deepwater reservoirs, zones and basins are now for the first time being exploited all around the world: in the Northeast Atlantic west of the Shetland islands; off the coast of Brazil (the Compos Basin); off the deepwater coast of West Africa (Guinea and Angola); and off the Northeast coast of Australia, to name a few locations. From 2001 to 2004, 11 new, major oil fields have been found at ocean depths of 7,000 feet (some two kilometres) or more.

Second, these emerging new deepwater oil and gas resources require new and unique exploitation technology. Generally, deepwater and ultradeepwater drilling and production requires a balance between drilling to the 'pay zone' below the seabed and at the same time doing so in a way that keeps under control the tremendous pressure at the wellhead and that does not result in a blowout like the Deepwater Horizon and does not fracture the pipe or the geological formation holding the reservoir.

Traditional, shallow water drilling and production facilities anchored and fixed to seabed close to shore are not useful because at deepwater and ultradeepwater the depths are too great to use fixed facilities. At deepwater 
depths, mobility and size are the keys to drilling and production facilities. A new mobile oil drilling unit (MODU) has been developed for deployment at deepwater reservoir sites. ${ }^{6}$ MODUs for deepwater and ultra-deepwater drilling and production generally are of two types - semisubmersibles (such as the Deepwater Horizon) and drillships. Semisubmersibles are either towed to a drilling location or use their own propulsion systems to navigate to deepwater oil and gas sites. A drillship is a massive vessel that is modified to drill oil and gas wells. Both semisubmersibles and drillships are mobile at the well site during drilling and are manoeuvred by propellers and thrusters using dynamic positioning technology to stay positioned over the well site during drilling and production. These facilities are huge by comparison to small, shallow water, facilities fixed structurally to the ocean floor. For example, the Deepwater Horizon had 123 people 'on board', weighed some 33,000 tons and had four supporting decks of workspace on top of which an oil derrick reached 20 stories above the drilling platform.

Third, the great horizontal distances from shore and the great vertical distances from the ocean surface to the deepwater wellhead of deepwater and ultra-deepwater drilling and production facilities pose, special, extremely difficult challenges to deal with accidents at the wellhead on the seabed surface or below. Equipment and operations are accessible at the ocean floor only by remotely operated vehicles controlled by operators thousands of feet above the well. ${ }^{7}$ In addition, the conditions of low temperature and high pressure at the seabed add substantially to the complexity of facilities control. The BP blowout took three months to bring under control and to stop oil discharges after the explosion, in large part because the wellhead's distance from shore and depth below the ocean surface. Accidents at offshore, shallow water, fixed facilities are far more accessible for responders to accidents and are a different order of magnitude: lower in risk and potentially catastrophic harm.

\section{Legal uncertainties in the law of the sea applied to deepwater and ultra-deepwater drilling and production}

In its essential respects, the current international law of the sea addressed here predated the discovery of vast deepwater and ultra-deepwater oil and gas resources and the development of the technology to exploit those resources. The current law of the sea was mostly codified in 1958 in the four

6 For a description, see 'How Does a Drillship Work?', Rigzone, <www.rigzone.com/ training/insight.asp?i_id=306>.

7 Curry Hagerty and Jonathan Ramseur, 'Deepwater Horizon Oil Spill: Selected Issues for Congress', Congressional Research Service Report no. 7-5700, 30 July 2010. 
Geneva conventions on the law of $\operatorname{sea}^{8}$ and in 1982 in the Law of the Sea Convention. ${ }^{9}$

That codification confirms the historical evolution of systematic, creeping, coastal state jurisdiction over the oceans and ocean activities - for example, extension of the territorial sea of coastal states from three to twelve miles, the recognition of coastal resource jurisdiction over the continental shelf and the establishment of the 200-mile exclusive economic zone (EEZ) extending coastal state resource jurisdiction over seabed and superjacent water column.

The phenomenon of deepwater and ultra-deepwater oil and gas exploitation using MODUs reveals uncertainties in the law of the sea, which ought to be resolved in some definite manner. Those uncertainties in the law of the sea as presently codified include uncertainty about the legal status of MODUs, the jurisdiction of coastal states and the special peril posed to unique and diverse deepwater marine ecosystems.

\subsection{Uncertainty in the legal status of deepwater and ultra-deepwater mobile oil drilling units}

One legal uncertainty about MODUs used for deepwater and ultradeepwater oil and gas exploitation is whether under the law of the sea they have the legal status of ships (vessels) or of offshore installations or both? ${ }^{10}$ This is not a new question. However, it is one that remains unresolved with clarity in the context of spills and that continues to create uncertainties in the legal status of MODUs used for deepwater and ultra-deepwater oil and gas drilling and exploitation.

Both the 1958 Geneva Conventions on the law of the sea and the 1982 Law of the Sea Convention refer to ships and vessels, and to offshore installations, devices and structures. However, nowhere are these terms defined.

MODUs are considered to be ships or vessels because they navigate by selfpropulsion from deepwater site to deepwater site and also move by self-propulsion with propellers, thrusters and GPS positioning technology while on-site drilling and even during production. As ships, they have the right of freedom of navigation that other ships have not only on the high seas

8 Convention on the High Seas, 29 April 1958, in force 30 September 1962, 450 UNTS 11; Convention on the Continental Shelf, 29 April 1958, in force 10 June 1964, 499 UNTS 311; Convention on the Territorial Sea and the Contiguous Zone, 29 April 1958, in force 10 September 1964, 516 UNTS 205; Convention on Fishing Conservation of the Living Resources of the High Seas, 29 April 1958, in force 20 March 1966, 559 UNTS 285.

9 UNCLOS, 10 December 1982, in force 16 November 1994, 1833 UNTS 3.

10 See Hossein Esmaeili, The Legal Regime of Offshore Oil Rigs in International Law (Ashgate, 2001), at 20-68. Another remote possibility is that MODUs because of their sheer size might be considered 'artificial islands'. However, artificial islands are more akin to permanent attachment to the seabed with 'landfill' (rocks and soil) than to free-floating oil and gas facilities not fixed to the seabed. 
but also in the waters of the EEZ. MODUs as ships or vessels also have the right of innocent passage in the territorial sea and straits used for international navigation and they would have the nationality of the state whose flag they fly.

As ships or vessels, deepwater MODUs typically are registered with an openregistry, flag of convenience state. The Deepwater Horizon was registered in the Marshall Islands and flew its flag. MODUs as ships or vessels may be subject to non-binding, 'soft law', maritime industry codes ${ }^{11}$ addressing construction standards, vessel design and equipment requirements. As ships or vessels, MODUs may be subject to certification inspections (for mortgage, insurance and marketing purposes) by so-called shipping industry 'classification societies', such as the American Bureau of Shipping and Det Norske Veritas, which are concerned with physical characteristics of ships. In the BP spill, the US Coast Guard concluded that the Marshall Islands as flag state of the Deepwater Horizon 'entrusted all flag state duties' to classification societies 'without sufficient oversight which may have been [a] factor' in the accident. ${ }^{12}$

For MODUs that are foreign flagged ships or vessels, this may limit coastal state authority in the territorial sea or EEZ. For example, the US Coast Guard exercised only limited inspection authority over the Deepwater Horizon in terms of vessel 'seaworthiness' concerns and 'not the drilling aspects' of the rig. ${ }^{13}$ This included Coast Guard oversight limited to such matters as hull structure, navigation equipment, lifesaving equipment, fire protection and worker health and safety. The US Government Accounting Office (GAO) found the 'Coast Guard's scheme for overseeing the safety of foreign-flagged MODUs [to be] insufficient because it defers heavily to the flag to ensure safety'. ${ }^{14}$ Oddly, Coast Guard authority was limited to areas of the Deepwater Horizon above the water line and not to 'the sub platform' (i.e. underwater or seafloor) drilling systems. ${ }^{15}$

Alternatively, MODUs also have the status of an offshore installation, device or structure used to explore and exploit deepwater oil and gas reserves. The 1958 Continental Shelf Convention in Section 5(2) refers to 'installations and other devices necessary for ... [continental shelf]

11 Such as the Code for the Construction and Equipment of Mobile Offshore Drilling Units, IMO Res. A.1023(26), 2 December 2009.

12 'Explosion, Fire Sinking and Loss of Eleven Crew Members Aboard the Mobile Offshore Drilling Unit Deepwater Horizon in the Gulf of Mexico', 20-2 April 2010, Comments of the Commandant, United Sates Coast Guard, September 2011 at 3.

13 Hagerty and Ramseur, 'Selected Issues', supra note 7, at 38.

14 Stephen L. Caldwell and Frank Rusco 'Deepwater Horizon: Coast Guard and Interior could Improve their Offshore Energy Inspection Programs', Testimony before the Subcommittee on Coast Guard and Maritime Transportation, Committee on Transportation and Infrastructure, House of Representatives, US Government Accountability Office Doc. no. GAO-12-203T, 2 November 2011, at 10.

15 Curran Hagerty and Jonathan Ramseur, 'Deepwater Horizon Oil Spill: Highlighted Actions and Issues', Congressional Research Service, 13 September 2010, at 2-3. 
exploration and exploitation of ... natural resources'. The 1982 Law of the Sea Convention in Articles 60 and 80 refers to 'installations and structures' in the EEZ and continental shelf, respectively. Under both treaties, the coastal state has authority over permissions, construction and operation of deepwater oil and gas drilling and production facilities in those maritime zones.

As an installation, device or structure engaged in oil and gas exploitation of the US EEZ seabed, the Deepwater Horizon fell under the authority, not of the US Coast Guard, but of the US Minerals Management Service (now the Bureau of Ocean Energy Management, Regulation and Enforcement [BOEMRE]) of the Department of Interior, which regulates leasing of drill sites, exploration and exploitation operations and deals with environmental issues.

This split in status of deepwater MODUs such as the Deepwater Horizon as both ship and installation also contributes to operational uncertainty. US practice apparently is treat MODUs as ships until the rig is connected to the wellhead ('latched') and to treat it as an installation until it is 'unlatched' from the wellhead (even though it continues to move and manoeuvre by propellers and thrusters while latched) ${ }^{16}$ In the Deepwater Horizon explosion and blowout, there was uncertainty on the part of those involved including the crew as to who was in charge - the MODU operator, Transocean or the captain of the MODU. ${ }^{17}$

\subsection{Uncertainty in coastal state jurisdiction}

When the law of the sea was mostly codified in the late 1950s and early 1980s, the jurisdiction of coastal states over oil and gas drilling and production was certain. Offshore oil and gas facilities were in shallow waters close to shore and the facilities were installations fixed firmly to the seabed. Those facilities located variously in the territorial sea, in the continental shelf and/or in the EEZ were, and are, subject to coastal state exclusive jurisdiction, which assures that the coastal has complete jurisdiction over leasing, exploration and exploitation over oil gas resources in the seabed of those maritime zones and over the authorisation, establishment, use and operations of oil and gas installations and structures. ${ }^{18}$

16 Rebecca K. Richards, 'Deepwater Mobile Oil Rigs in the Exclusive Economic Zone and the Uncertainty of Coastal State Jurisdiction', 10 Journal of International Business E Law (2011) 387-411, at 423 .

17 Ibid. at 423. The Republic of The Marshall Islands acknowledged that there 'were instances of confusion regarding decision making authority during the casualty' that posed 'challenges for maintaining a clear command structure, especially in emergency situations'. However, it did not accept that the confusion 'was a causal factor in the causality'. Deepwater Horizon Marine Causality Investigation Report, Republic of the Marshall Islands, IMO Doc. 8764597, 17 August 2011, at ii.

18 Convention on the Territorial Sea and the Contiguous Zone, supra note 8, Article 2; Continental Shelf Convention, supra note 8, Article 2(1); UNCLOS, supra note 9, Articles $2(2), 56,57,60,77$ and 80 . 
With the emergence of deepwater and ultra-deepwater oil and gas resource exploration and exploitation and use of MODUs in the late 1990s, coastal state jurisdiction is far less certain. Churchill and Lowe aptly summarised (without explanation) the uncertainty with regard to coastal state jurisdiction and deepwater MODUs:

Coastal state jurisdiction [under the law of the sea] is plainly an inadequate basis for the regulation of such mobile units [i.e. MODUs] and activities upon them. Yet neither the 1958 [Continental Shelf] Convention nor the 1982 Convention deals specifically with the issue. $^{19}$

That inadequacy may produce uncertainty in coastal state jurisdiction over deepwater and ultra-deepwater MODUs in several respects. First, as mentioned above, the status of MODUs as, at the same time (or alternatively), foreign vessels and ships subject to flag state jurisdiction and also oil and gas installations, devices and structures subject to exclusive coastal state jurisdiction makes determining the extent of coastal state control at a particular stage of exploitation or moment sometimes difficult to ascertain. Second, with respect to the outer limits of continental shelf where deepwater and ultra-deepwater oil reservoir zones are located, coastal state jurisdiction may be limited in ways not experienced with shallow water reservoirs closer to shore. For example, with regard to coastal state authority in the outer continental shelf beyond 200 miles, the superjacent waters in which MODUs operate are high seas and not part of the EEZ of a coastal state. In addition, if oil and gas resources are exploited by deepwater and ultra-deepwater MODUs in this part of the ocean floor, the coastal state (although it has exclusive exploitation rights) must pay a portion of the site value to the International Seabed Authority after the first five years of production..$^{20}$ In any event, the legal questions surrounding the actual determination of precise outer limits of coastal state jurisdiction over oil and gas reservoirs, are sufficiently unwieldy that the 1982 Law of the Sea Convention in Annex II establishes a 21-person Commission on the Limits of the Continental Shelf to sort them on a case by case basis where claims extend beyond 200 nautical miles from the baselines from which the breadth of the territorial seas is measured. ${ }^{21}$ Those outer limits at deepwater depths are also difficult to determine because the ocean floor's configuration is constantly changing

19 R. R. Churchill and A. V. Lowe, The Law of the Sea (3rd edn, Manchester University Press, 1999), at 154.

20 UNCLOS, supra note 9, Article 82.

21 'Despite its detail, the formula [for continental shelf delimitation] in the 1982 Convention leaves room for considerable uncertainty'. Churchill and Lowe, Law of the Sea, supra note 16 at 149. See Donald Rothwell, 'Issues and Strategies for Outer Continental Shelf Claims', 23 International Journal of Marine and Coastal Law (2008) 185-211. 
and some areas have not been charted or are in need of re-charting. The isobaths (used in some delimitations) are not easy to determine, and at deepwater and ultra-deepwater sites, the nature, composition and thickness of sedentary rock may simply not be known with any confident degree of certainty. ${ }^{22}$ That information is important to separate coastal state jurisdiction over continental shelf, continental shelf beyond 200 miles and from the geological deep seabed beyond the limits of coastal state jurisdiction subject to the International Seabed Authority.

\subsection{The unique peril posed by deepwater and ultra-deepwater operations to deepwater marine ecosystems}

Not addressed specifically by the current codified law of the sea is the impact of deepwater and ultra-deepwater oil and gas drilling and production on unique deepwater marine ecosystems in the event of a spill like the Deepwater Horizon. As mentioned above, these ecosystems operate at high pressure, low light and cold temperatures not experienced by other marine ecosystems. In addition, these marine ecosystems are not directly accessible by humans. Reliance must be had on remotely operated vehicles from the ocean surface. The blowout of the Deepwater Horizon exposed 'deepwater ecosystems ... to large volumes of oil for an extended period' ${ }^{23}$ The Deepwater Horizon oil spill raised:

Public and scientific concern ... on the impacts ... of a deepwater plume of highly dispersed oil droplets and dissolved gases at between 3,200 and 4,200 feet deep and extending many miles ... [from] the wellhead. ${ }^{24}$

Those concerns included 'depletion of the oxygen supply on which aquatic species depend', 'potential impacts of deepwater oil and dispersant concentrations on individual species' and 'acute toxicity to exposed organisms' and 'reports of dead and dying deepwater corals'.$^{25}$ It has been estimated that over 1,700 species live in the marine ecosystem near the Macondo wellhead of the Deepwater Horizon. ${ }^{26}$

Unfortunately, 'scientific understanding of the deepwater ecosystem has not advanced with the industrial development of deepwater drilling and production': 27 'Scientists simply do not yet know how to predict the ecolo- 
gical consequences and effects on key species that might result from oil exposure in the water column ... far below ... the surface. ${ }^{28}$

This means that the required baseline information to assess and measure natural resources damages and to assign responsibility and to identify and impose restoration efforts are presently missing with regard to deepwater marine ecosystems affected by deepwater and ultra-deepwater oil and gas accidents like the Deepwater Horizon. Marine natural resources preservation and pollution prevention efforts 'presume sufficient prior knowledge to determine what is different after the spill' and such prior knowledge is 'generally lacking for deepwater ecosystems'. ${ }^{29}$

The current international law of the sea does not address this significant problem (nor do industry, national or regional efforts for that matter). The law of the sea as codified in the late 1950s and early 1980s has only general obligations and encouragements for states individually and cooperatively to protect and preserve the marine environment. For example, Article 24 of the 1958 High Seas Convention requires states to 'draw up' regulations 'to prevent pollution of the sea by discharge of oil' from 'the exploitation and exploration of the seabed and its subsoil'. Article 5(7) of the 1958 Continental Shelf Convention only obliges states to take 'all appropriate measures' to protect 'living resources of the sea from harmful agents'. The 1982 Law of the Sea Convention in Article 208(1) requires states in seabed under their jurisdiction 'to prevent, reduce and control pollution of the marine environment arising from' 'seabed activities' and 'installations and structures under their jurisdiction'. And Article 145 requires the International Seabed Authority to make rules for, inter alia, pollution prevention from deep seabed 'drilling' and the 'construction and operation or maintenance of installations' on the deep seabed.

\section{Conclusion}

The recent and continuing phenomenon of the exploration and exploitation of oil and gas in deepwater and ultra-deepwater reservoirs around the globe is growing at a significant rate. The 2010 BP Deepwater Horizon oil spill in the Gulf of Mexico underscores the uncertainty in the currently codified international law of the sea to deal with this phenomenon. Those uncertainties exist about the legal status under the law of the sea of deepwater and ultra-deepwater facilities for drilling and production of oil and gas. In addition, coastal states, which bear the potentially catastrophic harm from blowouts like the Deepwater Horizon, have uncertain jurisdiction to deal with the deepwater and ultra-deepwater oil and gas drilling and production.

29 Robin Craig, 'Legal Remedies for Deep Marine Oil Spills and Long-Term Ecological Resilience: A Match Made in Hell', 6 Brigham Young Law Review (2011) 1863-98, at 1885. 
Finally, there is legal uncertainty about how to deal with the harm to unique deepwater marine ecosystems affected by deepwater and ultra-deepwater accidents.

Those uncertainties and gaps in the law of the sea need to be filled. Some have called for a discrete comprehensive international legal treaty regime to deal with all aspects of all offshore oil rigs including deepwater and ultradeepwater facilities. ${ }^{30}$ Others have called for complete and certain coastal state regulatory jurisdiction over all deepwater and ultra-deepwater exploration and exploitation, reflecting a further extension of the historical creeping coastal state jurisdiction in the law of the sea. ${ }^{31}$

Perhaps what is needed is something 'in between' in the form of a discrete agreement aimed at resolving those legal uncertainties. There is precedent for such an approach. Uncertainties and gaps relating to fisheries conservation and management in the law of the sea were resolved by a special agreement. There, the 1982 Law of the Sea Convention acknowledges, but does not directly address, transboundary fishing cooperation among states and regional fishing organisations. That gap was partially filled in 1995 by the UN Fish Stocks Agreement (FSA) that addresses discretely the problems of straddling stocks (fish in both the high seas and EEZ) and highly migratory fish stocks. ${ }^{32}$

A similar agreement could be reached to remove the legal uncertainties associated with deepwater and ultra-deepwater oil and gas drilling. Such an agreement could serve several purposes. It could help to ensure protection and preservation of deepwater unique marine ecosystems, to clarify jurisdiction over MODUs, to help the efficient and relatively safe exploration and exploitation of oil and gas, to protect coastal communities and to make certain that coastal states have needed jurisdiction in recognition that overwhelmingly it is coastal states that suffer the potentially catastrophic consequences of an oil spill from deepwater and ultra-deepwater as shown by the BP Deepwater Horizon accident. At the end of the day, perhaps, it is not so important which pathway towards certainty in the law of sea is taken to address the problem, as it is that some law certain be made, and be made in the near future.

30 Esmaeili, Legal Regime, supra note 10, at 263.

31 Richards, 'Deepwater Mobile Oil Rigs', supra note 16, at 410-11.

32 Agreement for the Implementation of the UNCLOS of 10 December 1982 Relating to the Conservation and Management of Straddling Stocks and Highly Migratory Fish Stocks, , 4 August 1995, in force 11 December 2001, 2167 UNTS 3. 